\title{
MMP-2 Inhibitory Activity of PBS Extract of Guava Leaves
}

\author{
Atanu Mondal', Ramanuj Mukherjee ${ }^{2}$, Subhajit Mondal'1, Amitava Chatterjee ${ }^{{ }^{*}}$ \\ ${ }^{1}$ Ramakrishna Mission Vivekananda Educational \& Research Institute, Kolkata, India \\ ${ }^{2} \mathrm{R}$ G Kar Medical College, Kolkata, India \\ Email: *ac354843@gmail.com
}

How to cite this paper: Mondal, A., Mukherjee, R., Mondal, S., \& Chatterjee, A. (2021) MMP-2 Inhibitory Activity of PBS Extract of Guava Leaves. American Journal of Plant Sciences, 12, 1761-1767.

https://doi.org/10.4236/ajps.2021.1212122

Received: September 13, 2021

Accepted: December 5, 2021

Published: December 8, 2021

Copyright $\odot 2021$ by author(s) and Scientific Research Publishing Inc. This work is licensed under the Creative Commons Attribution International License (CC BY 4.0).

http://creativecommons.org/licenses/by/4.0/

\begin{abstract}
PBS (Phosphate Buffed Saline), pH 7.4 extract of Guava leaves (Psidium guajava L.) inhibits the active MMP-2 like molecule both of plant origin as well as active MMP-2 of human (breast cancer patients' saliva) origin. The zymogram and ELISA were developed of different samples following standard methods. The isolation and identification of the new MMP-2 inhibitor(s) for its molecular characterization is under investigation.
\end{abstract}

\section{Keywords}

MMP-2, Inhibitor, Guava Leaves, Cancer

\section{Introduction}

Ethnomedical searches for new bioactive molecules are becoming a promising field of science to discover a cure of different diseases. Traditionally, extract of different parts of guava (Psidium guajava L.) plants has been used from the ancient human history to treat different human illness. It is reported that guava leaves contain several phenolic compounds, which has shown to maintain a healthy blood glucose level efficiently [1]. Different world wild in vitro and in vivo research has demonstrated the potential pharmacological importance of leave extract can be a co-treatment for different physiological problems. Modern research acknowledges the importance of specific individual compounds from the bioactive guava leaves extract.

A study on human cancer reported that different compounds of guava leaves may have an anticancer activity and these compounds may inhibit the activation of AKT/mTOR/S6K1/MAPK pathway, but the detail mechanisms are not well understood yet [2]. The same study has also demonstrated a compound of guava 
leaves known as guava leaf hexane fraction (GHF) that can promote the production of different cytotoxic molecules and leads to cell death. GHF mediated apoptosis can be mediated by the inhibition of AKT/mTOR/S6K1/MAPK signaling pathway, but farther research needs to be done to understand the proper mechanisms [2]. These studies altogether propose that these molecules have the ability to suppress tumorigenesis by interfering several cell signaling pathways and thus it gives us a promising way to cure and prevent cancer.

The activity of MMP-2 is well related to the tumorigenesis and angiogenesis has been shown by several studies [3]-[11]. Several studies demonstrated that the activity of MMP-2 depends upon the activation of MT1-MMP [12] [13] and TIMP-2 [14]. Activated MT1-MMP positively regulates the level of active MMP-2 whereas TIMP-2 is reported to suppress its activity [12] [13] [14].

We prepared a simple $1 \times \mathrm{PBS}\left(\mathrm{pH}\right.$ 7.4) extract of Guava Leaves at $4^{\circ} \mathrm{C}$ especially to see whether PBS extract of guava leaves has any effect on MMP-2 activity and observed that guava leaves PBS extract inhibits very efficiently the plant derived active MMP-2 like molecule [15] and also it inhibits salivary active MMP-2 of human breast cancer patients [16]. This study in future may be an important part in the management of cancer.

\section{Methods \& Materials}

Guava Leaves was collected from RKMVERI's garden. The guava leaves was extracted using a Teflon homogenizer with cold $1 \times \mathrm{PBS}(\mathrm{pH}$ 7.4) in a proportion of $1: 5$ in ice at $4^{\circ} \mathrm{C}$ for $2 \mathrm{hrs}$. The homogenate guava leaves was then centrifuged at $10,000 \mathrm{rpm}$ at $4^{\circ} \mathrm{C}$ for 30 mins. The clear supernatant was saved and kept at $4^{\circ} \mathrm{C}$ as a source of the inhibitor of MMP-2. The zymography was run following the method of Bhattacharrya et al. [16]. The ELISA was run following the method of Mondal et al. [15]. The immunoblot was developed according to Mondal et al. [15]. The Gelatin was purchased from Sigma U.S.A. The monoclonal antibodies against MMP-2, MT1-MMP and TIMP-2 were purchased from Santa Cruz, USA.

\subsection{Zymography}

$50 \mu \mathrm{g}$ of PBS extract of every sample was run in 8\% SDS-PAGE. The zymogram was developed keeping the gel overnight ( $15 \mathrm{hrs})$ in a buffer $\left(\mathrm{NaCl} 0.2 \mathrm{M}, \mathrm{CaCl}_{2}\right.$ $4.5 \mathrm{mM}$, Tris $50 \mathrm{mM}, \mathrm{pH} 7.4)$ solution at $37^{\circ} \mathrm{C}$. The zymogram was developed staining the gel by Coommassie Brilliant Blue [16].

\subsection{ELISA}

$50 \mu \mathrm{g}$ of the extract (sample) in triplicate was added/well of the ELISA plates. Allow the plate with the samples to attach for one and half hour at $37^{\circ} \mathrm{C}$. The wells were then treated with 3\% BSA for $1 \mathrm{hr}$. After washing the primary antibody in a dilution of 1:2000 (Santa Cruz, USA) were then added (50 $\mu \mathrm{l})$ in triplicate and kept at $37^{\circ} \mathrm{C}$ for one and a half hour. After three washing (PBS con- 
taining $0.1 \%$ Tween-20), second antibody coupled with alkaline phosphatase (50 $\mu \mathrm{l}, 1: 2000$ diluted) was added in triplicate for one and half hour at $37^{\circ} \mathrm{C}$. The TMB substrate was added. The stop solution were added after development of colour and read at $540 \mathrm{~nm}$ [15].

\subsection{Immunoblot}

To develop immunoblot $200 \mu \mathrm{g}$ of salivary protein was run on $8 \%$ SDS-PAGE. The proteins were then transferred onto a nitrocellulose (NC) membrane electrically. The NC membrane was then blocked with 5\% BSA for 2 hours at $37^{\circ} \mathrm{C}$ in an incubator. Then after washing the membrane was reacted with MMP-2 primary monoclonal antibody (Santa Cruz, USA) for 1 and half hour followed by 2nd antibody coupled with alkaline phosphatase for the same time at $37^{\circ} \mathrm{C}$ after washing (3 times). The colour was then developed with NBT/BCIP following Bhattacharyya et al. [16].

\section{Results}

Figure 1(a) shows, lane 1 is the control bamboo leaf extract in PBSx1, pH 7.4 [16], lane 2 banana (Musa Sp) leaves extract, lane 3 is the coriander (Coriander sativum) leaves extract, lane 4 is the guava leaves extract, lane5 is the Nasturtium flower (Tropaeolum majus) extract and lane6 is the Nayantara flower (Catharanthus roseus) extract and lane 7 was extract from Gandal leaves (Paederia foetida) all materials were collected from RKMVERI's garden. $50 \mu \mathrm{g}$ of PBS, pH 7.4 extract was charged to develop Zymogram.This zymogram was developed to compare different leaves and flower extracts and also to observe whether the guava leaves extract express any gelatinase. When ELISA was done with these extracts it shows that only the Bamboo leaves extract and nasturtium flower extracts are showing ELISA positive with monoclonal MMP-2 antibody [15].

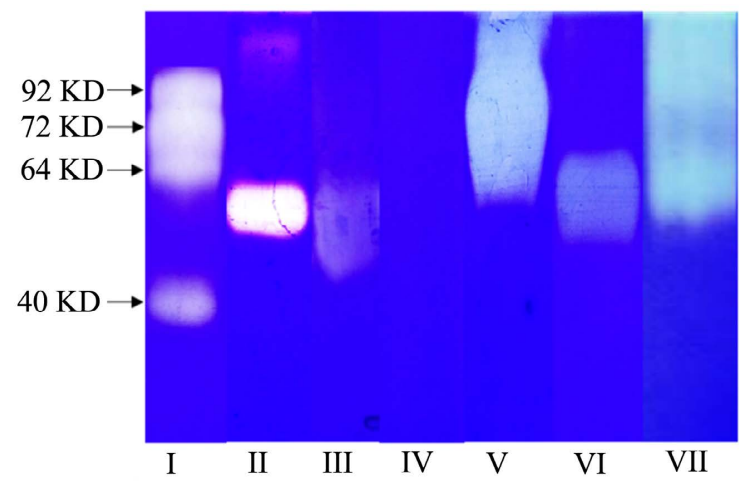

(a)

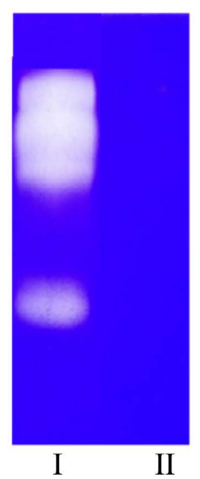

(b)

Figure 1. (a): Zymograph of PBS extract of I. Bambusa balcooa leaves II. Banana (Musa sp.) leaves III. Coriander (Coriandrum sativum) leaves IV. Guava (Psidium guajava) leaves V. Nasturtium (Tropaeolum majus) flower VI. Nayatara flower (Catharanthus roseus) VII. Gandal leaves (Paederia foetida). $50 \mu \mathrm{g}$ protein samples were used to run. (b): Zymograph of PBS extract of I. Bambusa balcooa leaves II. Bambusa balcooa leaves after treated with EDTA $(1 \mu \mathrm{g} / \mathrm{ml}) .50 \mu \mathrm{g}$ protein sample were used to run. 
Figure 1(b) shows that the MMP-2 like molecule in the zymogram inhibits completely in EDTA (1 mM) solution. Figure 2(a) shows addition of guava leave extract in increasing concentration to Bamboo leaves extract inhibits the activity of MMP-2 like molecule extracted with PBS from Bamboo leaves [15].

Figure 2(b) also shows that in case of different MMP like molecule (not MMP-2 like molecule according to ELISA) is not inhibited by guava leaves extract. Figure 3(a) shows that other MMP-2 like molecule [15] in Nayantara flower's PBS extract [15] and newly found gandal leaves PBS extract. Figure 3(b) (not published) the MMP-2 like molecule is also being inhibited by Guava leaves extract. Figure 3(c) confirms that ELISA of Gandal leaves and Nasturtium flower extracts are MMP-2 positive with MMP-2 monoclonal antibody. We asked the question that whether this is possible for the MMP-2 inhibitor of Guava Leaves has any effect on human MMP-2. In 2017 we published [16] that human breast cancer female patients saliva has very high activated MMP-2 [16]. We collected saliva from breast cancer patients from R G Kar Medical College, Kolkata. Figure 4(a) shows that the comparative zymogram confirms that activated MMP-2 of human Saliva origin is being appreciably inhibited by Guava leaves extract (we repeated the experiment in several cases). Figure 4(b) shows that the PBS extract of Guava Leaves can inhibit efficiently (graded response) of the active MMP-2 of human (Breast cancer patients saliva). We suspected whether this increase in MMP-2 activity is due to MT1-MMP and also whether this inhibitor of MMP-2 has any similarity with the known MMP-2 inhibitor that is TIMP-2. Figure 5(a) shows that the ELISA of Guava leaves PBS extract has no TIMP-2 like activity. Perhaps the ELISA result indicates that MMP-inhibitor(s) present in PBS extract of Guava Leaves may be new type of inhibitor other than TIMP-2. Figure 5(b) ELISA test using human MT1-MMP monoclonal antibody shows that MT1-MMP is present in appreciable amount in the Bamboo leaves extract.

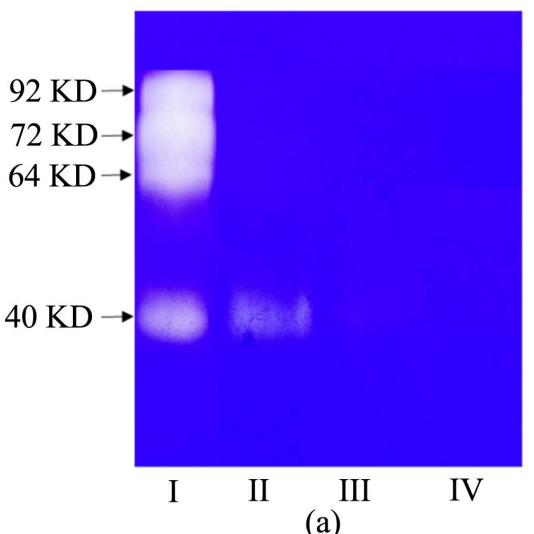

(a)

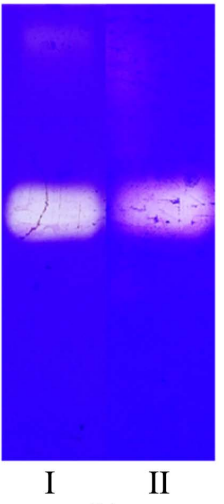

(b)

Figure 2. (a): Zymograph of $50 \mu \mathrm{g}$ Bambusa balcooa leaves with I. No guava leaves (Psidium guajava) extract II. $10 \mu \mathrm{l}(25 \mu \mathrm{g}$ protein) guava leaves (Psidium guajava) extract III. $20 \mu \mathrm{l}(50 \mu \mathrm{g}$ protein) guava leaves (Psidium guajava) extract IV. $30 \mu \mathrm{l}$ (75 $\mu \mathrm{g}$ protein) guava leaves (Psidium guajava) extract. (b): Zymograph of $50 \mu \mathrm{g}$ Banana leaves (Musa sp.) extract with I. No guava leaves (Psidium guajava) extract II. $20 \mu \mathrm{l}$ (50 $\mu$ g protein) guava leaves (Psidium guajava) extract. 


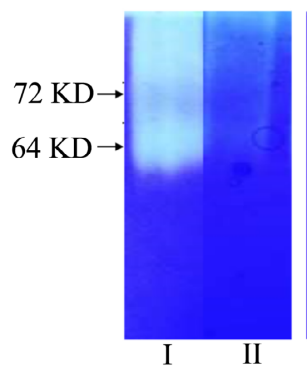

(a)

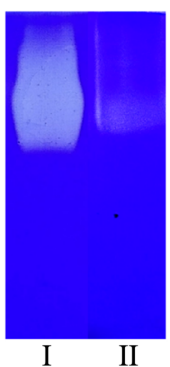

(b)

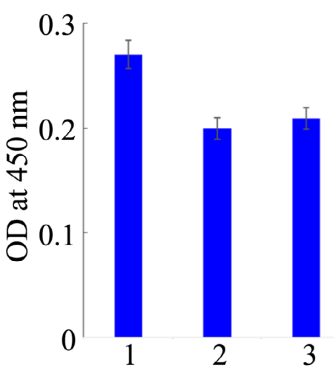

(c)

Figure 3. (a): Zymograph of $50 \mu \mathrm{g}$ gandal leaves (Paederia foetida) extract with I. No guava leaves (Psidium guajava) extract II. $20 \mu \mathrm{l}$ (50 $\mu \mathrm{g}$ protein) guava leaves (Psidium guajava) extract. (b): Zymograph of nasturtium flower (Tropaeolum majus) extract with I. No guava leaves ( $P$ sidium guajava) extract II. $20 \mu \mathrm{l}$ (50 $\mu$ g protein) guava leaves (Psidium guajava) extract. (c): ELISA of 1. Human serum 2. Gandal leaves (Paederia foetida) extract 3. Nasturtium flower (Tropaeolum majus) extract. For ELISA we used $50 \mu \mathrm{g}$ protein using monoclonal antibody against human/mouse MMP-2 (SantaCruz, USA), followed by secondary antibody coupled with HRP. TMB as substrate was used to develop the colour and reading was taken at $450 \mathrm{~nm}$.

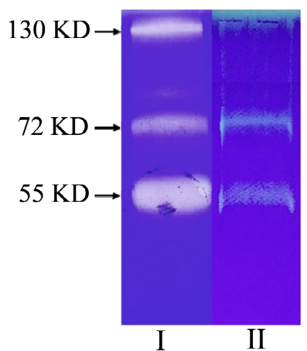

(a)

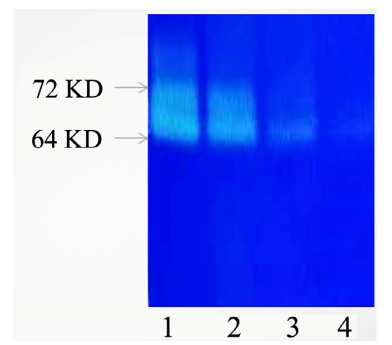

(b)

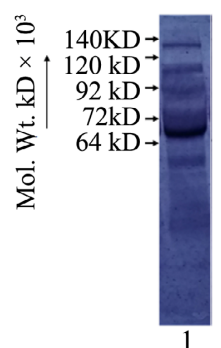

(c)

Figure 4. (a): Zymograph of I. Human breast cancer patient's saliva (50 $\mu$ g protein) II. Human breast cancer patient's saliva ( $50 \mu \mathrm{g}$ protein) with $20 \mu \mathrm{l}$ (50 $\mu \mathrm{g}$ protein) guava leaves (Psidium guajava) extract. (b): Another Breast cancer patient's saliva (lane 1, Control), Control plus added $5 \mu \mathrm{l}$ (lane 2), $10 \mu \mathrm{l}$ (lane 3) and $20 \mu \mathrm{l}$ (lane 4) of guava leaves (Psidium guajava) extract. (c): The Immunoblot of Breast cancer patient's saliva (200 $\mu \mathrm{g}$ of proteins) and reacted with anti MMP-2 monoclonal antibody.

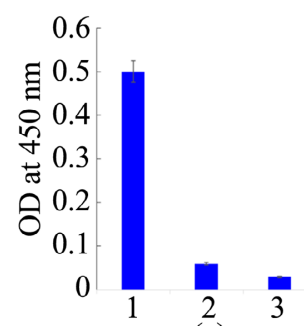

(a)

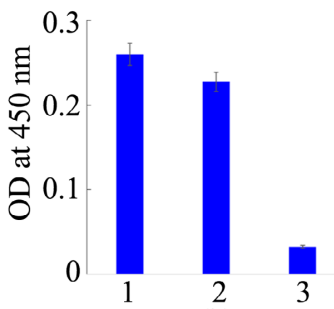

(b)

Figure 5. (a): ELISA of 1. Human serum 2. Guava leaves (Psidium guajava) extract 3. Reagent blank. For ELISA we used $50 \mu$ g protein using monoclonal antibody against human/mouse TIMP-2 (SantaCruz, USA), followed by secondary antibody coupled with HRP. TMB as substrate was used to develop the colour and reading was taken at $450 \mathrm{~nm}$. (b): ELISA of 1. Human serum 2. PBS extract of Bambusa balcooa leaves 3. Reagent blank. For ELISA we used $50 \mu \mathrm{g}$ protein using monoclonal antibody against human/mouse MT1-MMP (SantaCruz, USA), followed by secondary antibody coupled with HRP. TMB as substrate was used to develop the colour and reading was taken at $450 \mathrm{~nm}$. 


\section{Discussion}

Guava is reported to have bio active compounds to manage several diseases [1] [2]. Its anticancer effect was also reported [1] [2]. One of the major factors in cancer development is MMP-2 activity. MMP-2 activity is intimately related to the cancer development and angiogenesis. This has been studied and referred in several references [4] [12]. In our study, PBS, pH 7.4 extract of Guava Leaves show appreciable inhibition of active MMP-2 like molecule both from plant origin as well as human active MMP-2 (Breast Cancer patients' saliva). Our studies also through some light on the inhibition of activated MMP-2 like molecule derived from plant origin and also human MMP-2 (MMP-2 from human female breast cancer patient's saliva). ELISA results perhaps confirm that MT1-MMP like molecule is present in Guava leaves PBS extract. This could be a novel observation as well as could explain better why the Guava leaves extract shows anticancer effect [2]. The detail study could focus on the management of cancer.

The isolation and identification of the new MMP-2 inhibitor (other than TIMP-2) for its molecular characterization is under investigation.

\section{Conclusion}

Matrixmetalloproteinase-2 or MMP-2 is an enzyme protein very much associated with the development of cancer. It has been noticed that some inhibitor like molecule(s) may be present in the PBS extract of Guava Leaves those may inhibit the active MMP-2 like molecule of Plant origin as well as human active MMP-2. The active MMP-2 inhibitor(s) if identified may function in the management of Cancer.

\section{Acknowledgements}

We acknowledge the help and laboratory facilities, chemicals provided by the Vice Chancellor and Pro Chancellor of RKMVERI.

\section{Conflicts of Interest}

The authors declare that there is no conflict of interest.

\section{References}

[1] Díaz-de-Cerio, E., Verardo, V., Gómez-Caravaca, A.M., Fernández-Gutiérrez, A. and Segura-Carretero, A. (2017) Health Effects of Psidium guajava L. Leaves: An Overview of the Last Decade. International Journal of Molecular Sciences, 18, Article No. 897. https://doi.org/10.3390/ijms18040897

[2] Ryu, N.H., Park, K.R., Kim, S.M., Yun, H.M., Nam, D., Lee, S.G., Jang, H.J., Ahn, K.S., Kim, S.H., Shim, B.S., Choi, S.H., Mosaddik, A., Cho, S.K. and Ahn, K.S. (2012) A Hexane Fraction of Guava Leaves (Psidium guajava L.) Induces Anticancer Activity by Suppressing AKT/Mammalian Target of Rapamycin/Ribosomal P70 S6 Kinase in Human Prostate Cancer Cells. Journal of Medicinal Food, 15, 231-241. https://doi.org/10.1089/jmf.2011.1701

[3] Nagaset, H. and Woessner, J.F. (1999) Matrix Metalloproteinases. Journal of Bio- 
logical Chemistry, 274, 21491-21494. https://doi.org/10.1074/jbc.274.31.21491

[4] Di Cara, G., Marabeti, M., Musso, R., Riili, I., Cancemi, P. and Pucci Minafra, I. (2018) New Insights into the Occurrence of Matrix Metalloproteases -2 and -9 in a Cohort of Breast Cancer Patients and Proteomic Correlations. Cells, 7, Article No. 89. https://doi.org/10.3390/cells7080089

[5] Seiki, M. (1999) Membrane-Type Matrix Metalloproteinases. Apmis, 107, 137-143. https://doi.org/10.1111/j.1699-0463.1999.tb01536.x

[6] Curran, S. and Murray, G.I. (1999) Matrix Metalloproteinases in Tumour Invasion and Metastasis. Journal of Pathology, 189, 300-308. https://doi.org/10.1002/(SICI)1096-9896(199911)189:3<300::AID-PATH456>3.0.C O;2-C

[7] Schwartz, G.K., Kelsen, D., Albino, A.P. and Dc, W. (1993) Protein Kinase C: A Novel Target for Inhibiting Gastric Cancer Cell Invasion. Cancer, 85, 402-407.

[8] Chambers, A.F. and Matrisian, L.M. (1997) Changing Views of the Role of Matrix Metalloproteinases in Metastasis. Journal of the National Cancer Institute, 89, 1260-1270. https://doi.org/10.1093/jnci/89.17.1260

[9] Strongin, A.Y., Marmer, B.L., Grant, G.A. and Goldberg, G.I. (1993) Plasma Membrane-Dependent Activation of the 72-KDa Type IV Collagenase Is Prevented by Complex Formation with TIMP-2. Journal of Biological Chemistry, 268, 14033-14039. https://doi.org/10.1016/s0021-9258(19)85205-5

[10] Strongin, A.Y., Collier, I., Bannikov, G., Marmer, B.L., Grant, G.A. and Goldberg, G.I. (1995) Mechanism of Cell Surface Activation of 72-KDa Type IV Collagenase. Isolation of the Activated Form of the Membrane Metalloprotease. Journal of Biological Chemistry, 270, 5331-5338. https://doi.org/10.1074/jbc.270.10.5331

[11] Sil, H., Moulik, S., Singha, I., Mandal, S.S., Biswas, J. and Chatterjee, A. (2015) Activation of Matrix Metalloproteinase 2(MMP-2) in Breast Cancer Progression. Journal of Tumor, 3, 292-299.

[12] Quintero-Fabián, S., Arreola, R., Becerril-Villanueva, E., Torres-Romero, J.C., Arana-Argáez, V., Lara-Riegos, J., Ramírez-Camacho, M.A. and Alvarez-Sánchez, M.E. (2019) Role of Matrix Metalloproteinases in Angiogenesis and Cancer. Frontiers in Oncology, 9, Article No. 1370. https://doi.org/10.3389/fonc.2019.01370

[13] Murphy, G.J.P., Murphy, G. and Reynolds, J.J. (1991) The Origin of Matrix Metalloproteinases and Their Familial Relationships. FEBS Letters, 289, 4-7. https://doi.org/10.1016/0014-5793(91)80895-A

[14] Sato, H., Takino, T., Okada, Y., Cao, J., Shinagawa, A., Yamamoto, E. and Seiki, M. (1994) A Matrix Metalloproteinase Expressed on the Surface of Invasive Tumour Cells. Nature, 370, 61-65. https://doi.org/10.1038/370061a0

[15] Mondal, S., Bardhan, K., Dutta, A. and Chatterjee, A. (2018) Identification of Vertebrate MMP-2 and MMP-9 like Molecules in the Aqueous Extract of Nasturtium (Tropaeolum majus) Flowers, Bambusa balcooa Leaves and Nayantara (Catharanthus roseus) Flowers. Journal of Tumor, 6, 540-544.

[16] Bhattacharyya, N., Mondal, S., Ali, M.N., Mukherjee, R., Adhikari, A. and Chatterjee, A. (2017) Activated Salivary MMP-2-A Potential Breast Cancer Marker. The Open Conference Proceedings Journal, 8, 22-32. 